\title{
INVESTIGATION OF THE MAXIMUM FLOW TRENDS AND THEIR IMPACT ON RISK LEVELS OF SPILLWAYS
}

\author{
YENIGUN, K. ${ }^{{ }^{*}}-$ ULGEN, M. U. ${ }^{2}-$ AYDOGDU, M. H. ${ }^{3}-$ YENIGUN, I. $^{4}$ \\ ${ }^{I}$ Department of Civil Engineering, Faculty of Engineering, Harran University, \\ Osmanbey Campus, Şanliurfa, Turkey.
}

${ }^{2}$ Department of Civil Engineering, Institute of Natural and Applied Sciences, Harran University, Osmanbey Campus, Şanliurfa, Turkey.

${ }^{3}$ Faculty of Agriculture, Harran University, Osmanbey Campus, Şanliurfa, Turkey.

${ }^{4}$ Department of Environmental Engineering, Institute of Natural and Applied Sciences, Harran University, Osmanbey Campus, Şanliurfa, Turkey.

\author{
*Corresponding author \\ e-mail: kyenigun@hotmail.com \\ (Received $8^{\text {th }}$ Aug 2016; accepted $12^{\text {th }}$ Oct 2016)
}

\begin{abstract}
Flood discharge capacity is used as input parameter for spillway design, and it is sensitive to climate change effects. One of the main aims of climate studies is seeing the result of the variability of climatic parameters on water structures. So, the observed maximum flow must be evaluated by the view of trend analysis of maximum flow data. At the same time, changing the risk levels of spillways must be evaluated by risk analysis using same data. Thus, the relationship between maximum data flow and flood risk can easily be understood. Based on the updated observation data, new or existing spillways can be designed or rehabilitated accurately. Ten selected dams in Turkey are studied for evaluating the aim, while Mann-Kendall and Spearman's Rho tests are used for investigating trends. The MFOSM (Mean Value First Order Second Moment) and AFOSM (Advanced FOSM) methods are used for analyzing the risks. Using maximum flow parameters, the existence of trends and safety level of spillways are reported for selected dams. Results show us the process of observation of the updated maximum flow data, and its effect on risk levels for dam safety is crucial for prediction and prevention of the flood damages. Keywords: trend analysis, risk analysis, dam safety, flood, Turkey
\end{abstract}

\section{Introduction}

Dams are huge engineering structures constructed for different aims like power generation, irrigation, flood control, transportation, and so on. Dams control large amounts of water in their reservoir, so they are at risk all their lifetime. These risks can be classified as structural insufficiencies, earthquake risks, flood risks and other environmental risks (Cheng, 1993; Vischer and Hager, 1998; Cooper and Chapman, 1993). Providing safety for dams under the influence of these types of risks is of vital importance when possible catastrophic results of dam failure are considered.

Different researchers have compiled the several causes of dam failure, which are reported by ICOLD (International Commission on Large Dams), and they showed that two major causes of dam failure are: foundation problems and inadequate spillway (Kite, 1976; Uzel, 1991; Yenigun and Erkek, 2002). Additionally, inadequate spillway design has been held responsible for triggering the foundation problems, (ICOLD, 2014). For this reason, spillways are very important parts of dams, and so their design, construction, operation and maintenance must be considered very carefully. The major 
design parameter of spillways is maximum flood discharge capacity; and determination of this parameter is generally hard because of stochastic properties of maximum flows, which is highly affected by climate change or other factors.

Climate change is recently getting more and more popular because of its effects on the hydro system engineering systems. Climate change affects the primary input variable of hydro system engineering, which is weather event (particularly precipitation). Due to the effects climate change, floods and droughts take extreme values. In this context, Kang et al. (2007) have made some sensitivity analysis of the flood safety of Yongdam Dam, using different climate change models and have concluded that single-flood events are more critical in the long run. Zhang et al. (2008) have performed an analysis based on historical records of the Yangtze Delta, using power spectrum analysis and continuous wavelet transformation methods for detecting the changing characteristics of flood change. They have determined that climate change might increase the frequency of extreme weather events in the Yangtze Delta. Bouwer et al. (2010) have indicated that increasing trends of possible flood damages cause climate and socioeconomic changes through annual expected flood damages.

Many studies related to hydrometeorological events or their effects on technical structure or social parameters can be found. Chang et al. (2011) studied torrential rains and their sediment volume which have caused severe damages to infrastructure and loss of life, by typhoon events in Taiwan. Fatti and Patel (2013) focused on this in their study on flood risk in South Africa, and how risk perceptions influence local government and residents' disaster management methods.

Lee and You (2013) developed a framework for the management of reservoir risk in Taiwan. Research in South Sumatra showed that the risk of extreme precipitation would increase and the sea level rise under climate uncertainty (Suroso et al., 2013). Similarly, a study in Korea explained that variation in precipitation is likely to increase flood and drought risk, and this could be a burden to river management and dam operation in Korea (Jung et al., 2011).

Some other studies focused on flood risks and hazards in USA (Kalyanapu et al., 2013; Condon et al., 2015), China (Shi et al., 2014; Cheng et al., 2016; Jun et al., 2016), UK (Jamie, 2015), Spain (Egueen, 2015), and Iran (Robert, 2016). Sowers et al. (2011) evaluated climate change and water resources by the social view. Some researchers are focused on impact of climate change on water structure design or risk (Yerramilli, 2013; Stratz and Hussein, 2014).

In Turkey, Cicek and Duman (2015) studied seasonal and annual precipitation trends in Turkey. Demir and Kisi (2016) prepared a risk map for flood hazards under flood experiences in Samsun.

Sen et al. (2012) have performed regional climate model simulation for Turkey using ICTOP-RegCM3 climate model and IPCC-A2 climate scenario, and they have indicated overall increasing temperatures and decreasing precipitation for Turkey during the $21 \mathrm{st}$ century. Yenigun and Ecer (2013) have carried out trend analysis of maximum flow values, using overlay mapping technique on the Euphrates basin and they have clearly seen the effects of climate change using the overlay mapping technique. Chernet et al. (2014) have investigated possible climate change effects on future safety of the Aurland hydropower dams during future floods using different future climate scenarios, and they have found that there was a change in the magnitude of the floods. These studies show hydro systems effects of climate change, uncertainties, and risk of hydro system effects are required to be taken into account. 
One of the other major difficulties in hydro system engineering shows stochastic properties which cause increasing importance of risk and uncertainty analysis in water structures. In the last few decades, different risk analysis methods have been developed by researchers. Some of these methods can be categorized simply as Return Period, Safety Factor and Safety Margin, Monte Carlo Simulation, Integration and Second Moment Methods (Turkman, 1990; Yen and Tung, 1993; Yenigun, 2001). Each method has some advantages and disadvantages. Goodarzi et al. (2013) have created a chronological list of advances of major risk and uncertainty analysis in hydro system engineering.

After reviewing the literature extensively, we have seen only several studies related to only the occurrence of climatic change, and some related to only the climatic change reasons and their near effect on water resources. And, some studies focused on only the safety level of the water structures or similar problems. In general, a few studies have made analyses of the effects of hydro-meteorological parameter changes on the risk level of the spillways for large dams. Very few researchers observe the real behavior of the spillways as a part of large water structures under climatic changes. This encouraged us to work on this subject comprehensively including all parameters.

This study is principally aimed to determine whether there is a change on maximum flows and to observe the effect of that variation on spillway's risk levels. So, it will be possible to observe the existing dam performance under the changing maximum flow parameters. To do this, it is intended the usage of trend analysis methods for maximum flows and applying risk analysis methods to ascertain whether there is a danger in the spillways of selected dams. Risk analyses that are performed in this study, are not based simply on previous time series maximum flow parameters. They are additionally based on the spillway characteristics, reservoir flood damping coefficient and the probability that some of spillway gates are out of service. This increases the reliability of the risk analysis results indicated in Serinaldi and Kilsby (2015). As a case study, first, several dams are selected from the different regions of Turkey, and then trend and risk analysis are done. Maximum flow observations are used for representing flood characteristics in this study. In order to increase the rate of success of study, some dams (4 of 10) are selected from the previous studies studied by authors for past period and limited data by the authors.

\section{Material and Method}

\section{Study area}

The study area is Turkey, located at the intersection of Asia and Europe and located in $26^{\circ}-45^{\circ}$ eastern longitudes and $36^{\circ}-42^{\circ}$ northern latitudes. Turkey is located in the Mediterranean macroclimate region, but the geographical factors create some changes in climatic conditions (Ikiel, 2005). The hydrological characteristics of the country represent high spatial and temporal variability (Kahya et al., 2007). On the other hand, it can be indicated that Turkey is placed in the semi-arid climatic zone. In this study, different dams which symbolize the different regions of Turkey have been examined. These dams are represented in Figure 1. Stream flow gauging stations which flow observation data for investigated dams obtained from them are also shown in the same figure. Some properties about selected dams are tabulated in Table 1. Properties of streamflow gauging stations (Name and ID number) are given in Table 2. 
Table 1. Properties of selected dams [from DSI, (2015)]

\begin{tabular}{|c|c|c|c|c|c|c|c|c|c|c|c|}
\hline \multirow[b]{2}{*}{ Dam } & \multirow[b]{2}{*}{ Province } & \multicolumn{3}{|c|}{ Purpose } & \multirow[b]{2}{*}{ Type } & \multirow[b]{2}{*}{ Year } & \multirow{2}{*}{$\begin{array}{c}\text { Reservoir } \\
\text { Volume } \\
\left(\mathbf{1 0}^{6} \mathbf{m}^{3}\right)\end{array}$} & \multirow[b]{2}{*}{$\begin{array}{c}\text { Height } \\
\text { (m) }\end{array}$} & \multicolumn{3}{|c|}{ Spillway } \\
\hline & & $\mathbf{E}^{*}$ & $\mathbf{I}^{*}$ & $\mathbf{F}^{*}$ & & & & & $\begin{array}{c}\text { Spillway } \\
\text { Type }\end{array}$ & $\begin{array}{l}\text { Number } \\
\text { of Gates }\end{array}$ & $\begin{array}{c}\text { Discharge } \\
\text { Capacity } \\
\left(\mathrm{m}^{3} / \mathrm{sn}\right)\end{array}$ \\
\hline Çatalan & Adana & $\mathrm{x}$ & $\mathrm{x}$ & $\mathrm{x}$ & Earthfill & 1997 & 14.50 & 82 & Frontal, gated & 6 & 10055 \\
\hline Demirdöven & Erzurum & & $\mathrm{x}$ & & Earthfill & 1996 & 2.50 & 67 & $\begin{array}{l}\text { Frontal, } \\
\text { ungated }\end{array}$ & - & 198 \\
\hline Manavgat & Antalya & $\mathrm{x}$ & $\mathrm{x}$ & $\mathrm{x}$ & Earthfill & 1987 & 1.20 & 29 & Frontal, gated & 3 & 4000 \\
\hline Oymapınar & Antalya & $\mathrm{x}$ & & & Concrete Arch & 1984 & 0.68 & 185 & Frontal, gated & 4 & 3600 \\
\hline Almus & Tokat & $\mathrm{x}$ & $\mathrm{x}$ & $\mathrm{x}$ & Earthfill & 1966 & 3.41 & 95 & Side channel & - & 2243 \\
\hline Arpaçay & Kars & & $\mathrm{x}$ & & $\begin{array}{c}\text { Concrete } \\
\text { Gravity }\end{array}$ & 1983 & 0.16 & 59,1 & $\begin{array}{c}\text { Frontal, } \\
\text { ungated } \\
+ \\
\text { uncontrolled } \\
\text { shaft }\end{array}$ & - & 752 \\
\hline Aslantaş & Adana & $\mathrm{x}$ & $\mathrm{x}$ & $\mathrm{x}$ & Earthfill & 1984 & 8.49 & 95 & Frontal, gated & 6 & 14280 \\
\hline Çaygören & Balıkesir & $\mathrm{x}$ & $\mathrm{x}$ & $\mathrm{x}$ & Earthfiil & 1971 & 3.41 & 53,5 & Frontal, gated & 7 & 2850 \\
\hline Kayaboğazı & Kütahya & & $\mathrm{x}$ & $\mathrm{x}$ & Earth+Rockfill & 1987 & 0.63 & 45 & Frontal, gated & 3 & 1998 \\
\hline Kemer & Aydın & $\mathrm{x}$ & $\mathrm{x}$ & $\mathrm{x}$ & $\begin{array}{c}\text { Concrete } \\
\text { Gravity }\end{array}$ & 1958 & 0.74 & 113,5 & $\begin{array}{l}\text { Frontal, } \\
\text { ungated }\end{array}$ & - & 5000 \\
\hline
\end{tabular}


Table 2. Properties of streamflow gauging stations

\begin{tabular}{|c|c|c|c|}
\hline Dam & Station ID & Place & Location \\
\hline Çatalan & E18A018 & Adana/Kozan & $37: 25: 25 \mathrm{~N} 35: 27: 17 \mathrm{E}$ \\
\hline Demirdöven & D24A016 & Erzurum/Pasinler & $40: 02: 05 N$ 41:44:07E \\
\hline Manavgat & E09A901 & Antalya/Akseki & $36: 56: 51 \mathrm{~N} 31: 31: 01 \mathrm{E}$ \\
\hline Oymapınar & E09A901 & Antalya/Akseki & $36: 56: 51 \mathrm{~N} 31: 31: 01 \mathrm{E}$ \\
\hline Almus & E14A018 & Tokat/Almus & $40: 18: 42 \mathrm{~N} 37: 07: 43 \mathrm{E}$ \\
\hline Arpaçay & $\mathrm{E} 24 \mathrm{~A} 018$ & Kars/Akyaka & $40: 44: 08 \mathrm{~N} 43: 33: 12 \mathrm{E}$ \\
\hline Aslantaş & D20A046 & Osmaniye/Kadirli & $37: 26: 51 \mathrm{~N} 36: 15: 16 \mathrm{E}$ \\
\hline Çaygören & D03A034 & Balıkesir/Sındırg1 & $39: 15: 31 \mathrm{~N} 28: 19: 28 \mathrm{E}$ \\
\hline Kayaboğazı & $\begin{array}{l}\text { D03A020 } \\
\text { D03A083 }\end{array}$ & Kütahya/Tavşanlı & $\begin{array}{l}39: 25: 53 \mathrm{~N} 29: 36: 34 \mathrm{E} \\
39: 19: 39 \mathrm{~N} 29: 37: 33 \mathrm{E}\end{array}$ \\
\hline Kemer & E07A004 & Aydın/Nazilli & $37: 36: 27 \mathrm{~N} 28: 28: 49 \mathrm{E}$ \\
\hline
\end{tabular}

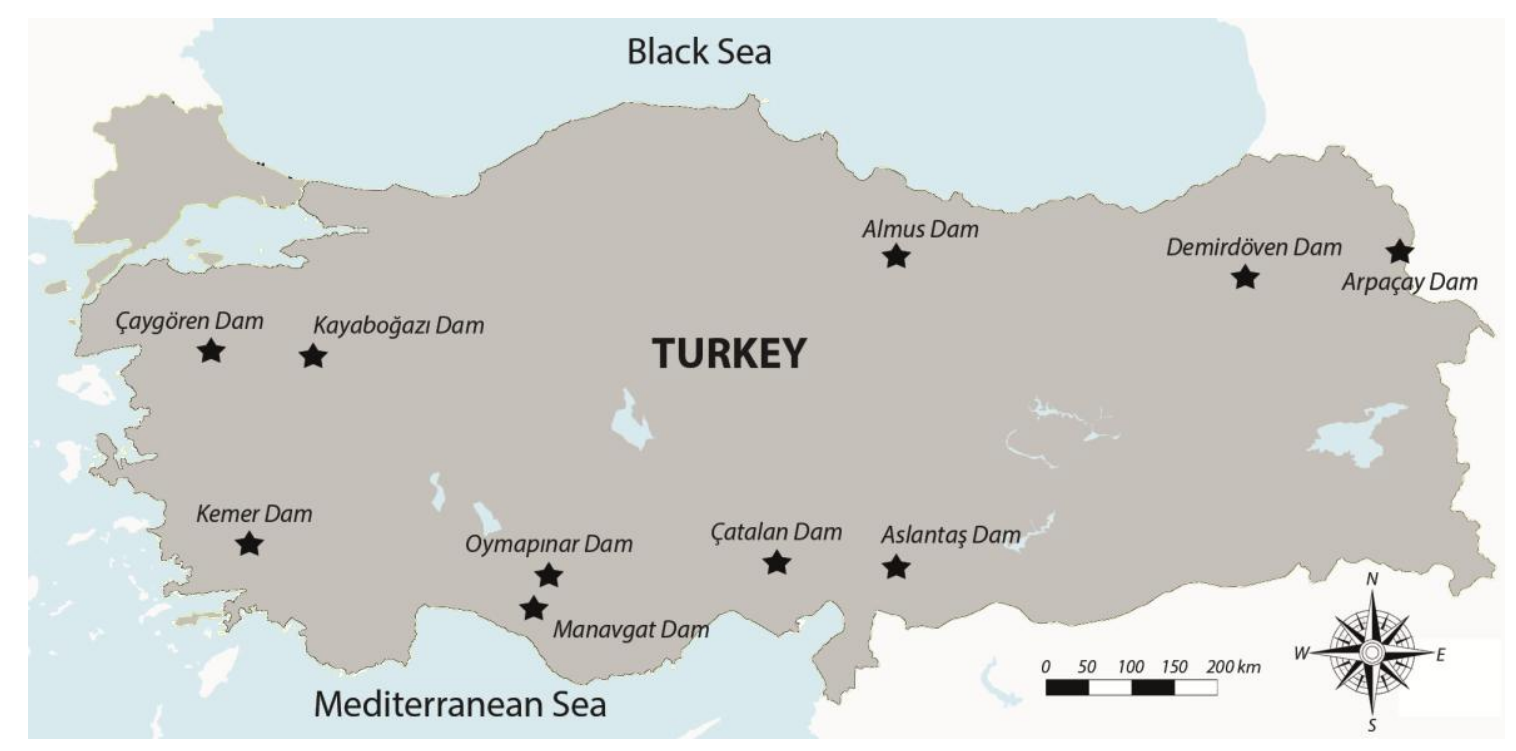

Figure 1. Study area, selected dams, and streamflow gauging stations - adopted from DSI

(2015)

In this study, some dams are selected from the previous studies which are studied by the authors for past period and limited data to compare the variation of the risk levels between past and present times. These dams are Çatalan, Demirdöven, Manavgat and Oymapinar Dams (Yenigun and Erkek, 2002a, 2002b; Yenigun, 2001; Yenigun, 2007).

\section{Data}

Maximum flow values are used due to represent flood conditions in the risk analysis. Data used in the analysis are obtained from General Directorate of State Hydraulic Works (Turkish abbreviation "DSİ"). It is considered important that the data used in the 
study covers a long time and is continuous. Table 3 shows the general statistical parameters of data used in this study.

Table 3. General statistical properties of used data

\begin{tabular}{|c|c|c|c|c|c|c|}
\hline \multirow[b]{2}{*}{ Dam } & \multirow[b]{2}{*}{ Station Name } & \multirow{2}{*}{$\begin{array}{l}\text { Elevation } \\
\quad(\mathbf{m})\end{array}$} & \multirow{2}{*}{$\begin{array}{c}\text { Precipitation } \\
\text { Area }\left(\mathbf{k m}^{2}\right)\end{array}$} & \multicolumn{3}{|c|}{ Statistics } \\
\hline & & & & $\operatorname{Mean}\left(\mathrm{m}^{3} / \mathrm{s}\right)$ & $\begin{array}{l}\text { Standard } \\
\text { deviation }\end{array}$ & Skewness \\
\hline Çatalan & Seyhan N. (Üçtepe) & 148 & 13740.6 & 1120.068 & 552.652 & 1.526 \\
\hline \multirow{2}{*}{ Demirdöven } & Tımar Ç. (Demir D.) & 1738 & 102.7 & \multirow{2}{*}{10.906} & \multirow{2}{*}{5.248} & \multirow{2}{*}{1.403} \\
\hline & Tımar Ç. (Tımar) & 1801 & 97.5 & & & \\
\hline \multirow{2}{*}{ Manavgat } & Manavgat (Homa) & 25 & 928.4 & \multirow{2}{*}{633.217} & \multirow{2}{*}{212.501} & \multirow{2}{*}{0.605} \\
\hline & Manavgat (S.Hoca) & 245 & 625.6 & & & \\
\hline \multirow{2}{*}{ Oymapınar } & Manavgat (Homa) & 25 & 928.4 & \multirow{2}{*}{633.217} & \multirow{2}{*}{212.501} & \multirow{2}{*}{0.605} \\
\hline & Manavgat (S.Hoca) & 245 & 625.6 & & & \\
\hline Almus & Yeşilırmak N. (G.Önü) & 820 & 1608 & 177.339 & 64.725 & 1.813 \\
\hline Arpaçay & Kars Ç. (Şahnalar) & 1495 & 4890.8 & 186.990 & 133.584 & 2.401 \\
\hline Aslantaş & Keşiş S. (Sarı D.) & 200 & 420 & 198.621 & 105.633 & 1.523 \\
\hline Çaygören & Simav Ç. (Osmanlar) & 271 & 1253.9 & 167.515 & 89.243 & 0.691 \\
\hline \multirow{2}{*}{ Kayaboğazı } & Kocadere (Akçay) & 873 & 1082.7 & \multirow{2}{*}{104.636} & \multirow{2}{*}{149.262} & \multirow{2}{*}{2.846} \\
\hline & Kocadere (Esatlar) & 945 & 847 & & & \\
\hline Kemer & Akçay (Amasya) & 155 & 3138 & 202.653 & 231.583 & 2.079 \\
\hline
\end{tabular}

The selection of these stations is based on the record length, reliability and continuity of the data. The data used in study cover the same period. Long-term recorded daily meteorological data are employed in the study. In previous studies, Çatalan, Manavgat, Demirdöven and Oymapınar dams were studied between 1960 and 1990. In addition to the four dams, the up to 2012 period data implemented in trend and risk analysis for 10 dams. Measurement devices and measurement techniques are reliable, so the probable errors in the measurements are not taken into account in the analysis. The analysis is based on the data given by DSİ measurements. The rivers with streamflow gauging stations are not regulated by large storage reservoirs and are not affected by urbanization; they have relatively natural flows. Therefore, in the analysis, it is considered that there are no potential anthropogenic effects on the catchment (Yenigun and Ecer, 2013).

To observe the trends in maximum flow data and possible effects of these trends on risk values of selected dams' spillways, trend and risk analysis within the scope of this study were performed.

\section{Trend detection tests}

In statistical terms, the purpose of trend analysis is to determine if a series of observations of a random variable is generally increasing or decreasing with time, or whether the probability distribution has changed with time. Several tests are available for the detection and quantification of trends, such as non-parametric, mixed and parametric (Helsel and Hirsch, 1992). Non-parametric tests are widely used in trend 
analysis of climatic and hydrologic data, which are robust concerning missing and tied values, seasonality, non-normality, non-linearity, and serial dependency. In this study, non-parametric Mann-Kendal and Spearman's Rho tests are used in trend detection.

The Mann-Kendall method was primarily developed for detecting the trends in hydrological time series by Mann (1945) and Kendall (1975). The World Meteorological Organization-WMO- (1988), also suggested it. The Mann- Kendall test statistic (S) is given by

$$
S=\sum_{i=1}^{n-1} \sum_{j=i+1}^{n} \operatorname{sign}\left(x_{j}-x_{i}\right)
$$

where $n$ is number of data, $x$ is data point at times $i$ and $j(j>i)$, and the sign function is given as

$$
\operatorname{sign}\left(x_{j}-x_{i}\right)=\left\{\begin{array}{cl}
+1 & x_{j}>x_{i} \\
0 & x_{j}=x_{i} \\
-1 & x_{j}<x_{i}
\end{array}\right.
$$

The variance of $S$ is computed by

$$
\operatorname{Var}(S)=\left[n(n-1)(2 n+5)-\sum_{i=1}^{m} t_{i} i(i-1)(2 i+5)\right] / 18
$$

where $t_{i}$ is the number of ties of extent $i$ and $m$ is number of tied rank groups. For $n$ larger than 10, the standard normal $\mathrm{Z}$ test statistic is computed as Mann- Kendall test statistic as follows:

$$
Z=\left\{\begin{array}{cc}
\frac{S-1}{\sqrt{\operatorname{Var}(S)}} & S>0 \\
0 & S=0 \\
\frac{S+1}{\sqrt{\operatorname{Var}(S)}} & S<0
\end{array}\right.
$$

The presence of a statistically significant trend is evaluated using the $\mathrm{Z}$ value. In a two-sided test for trend, the null hypothesis Ho should be accepted if $1 Z 1 \leq Z_{\alpha / 2}$ at the level of significance. A positive $S$ value indicates an 'upward trend,' and a negative value indicates a 'downward trend.'

The presence of serial correlation may lead to an erroneous rejection of the null hypothesis. So, the effect of a serial correlation problem should be taken into account in the Mann-Kendall test. The solution for removing the serial correlation from a dataset is pre-whitening (Burn and Elnur, 2002; Marengo et al., 1998; Yue et al., 2003). There are detailed information for pre-whitening in Burn and Elnur (2002), Birsan et al. (2005), Hamed and Rao (1998) and Yue et al. (2003). In this study, the pre-whitening procedure was applied to the dataset before executing the tests. 
Rank-based non-parametric statistical Spearman's Rho can also be used to detect monotonic trends in a time series. In this test, there is a significant trend only if the correlation between time steps and streamflow observations are found to be significant.

Given a sample dataset $\left\{\mathrm{x}_{\mathrm{i}}, \mathrm{i}=1,2, \ldots, \mathrm{n}\right\}$, the null hypothesis Ho of the Spearman's Rho test against trend tests is that all xi's are independent and identically distributed, whereas the alternative hypothesis is that $\mathrm{x}_{\mathrm{i}}$ increases or decreases with $\mathrm{i}$, that is, there is a trend. The test statistic is given by Sneyers (1990):

$$
r_{s}=1-\frac{\left.6\left[\sum_{i=1}^{n}\left(R\left(x_{i}\right)-i\right)\right)^{2}\right]}{\left.\left(n^{3}-n\right)\right)}
$$

where $\mathrm{R}\left(\mathrm{x}_{\mathrm{i}}\right)$ is the rank of $\mathrm{i}$-th observation $\mathrm{x}_{\mathrm{i}}$ in the sample of size $\mathrm{n}$. The standard normal distribution is used, the test statistic of $r_{s}, z$, is computed by

$$
z=r_{s} \sqrt{n-1}
$$

If $l z l>z_{\alpha}$ at a significance level of $\alpha$, then the null hypothesis of no trend (in other words, values of observations are identically distributed) is rejected. The details of these methods are given by Yenigun et al. (2008) and Yenigun and Ecer (2013).

\section{Risk Analysis Methods}

Risk analysis methods can be classified according to their capability, applicability, required computational power, and precision. At this point, MFOSM (Mean Value First Order Second Moment) and AFOSM (Advanced First Order Second Moment) methods offer an optimum point between precision and applicability. Generally, in engineering applications, capacity and load functions are not defined properly and only parameters of these variables are expected values and variances (Yenigun, 2001). Further, using Taylor series expansion in the MFOSM and AFOSM simplifies the difficulty in finding the probability density function of continuous and discrete variables (Goodarzi et al., 2013). The only difference between MFOSM and AFOSM is using average or actual values of performance function variables in Taylor series expansion. These methods should be used when variables obey normal distribution. Conversely, transformation functions should be used when observation values show different distribution types besides the normal. In this study, risk analyses performed by evaluating different scenarios like some of spillway gates are broken, experiencing design flood or specified n-years flood.

In MFOSM method, the first degree Taylor series expansion of performance function of $\mathrm{z}=\mathrm{g}\left(\mathrm{x}_{\mathrm{i}}\right),(\mathrm{i}=1,2 \ldots \mathrm{m})$ can be is written in terms of averages, $\overline{\mathrm{x}}_{\mathrm{i}}$, as

$$
\mathrm{z}=\mathrm{g}\left(\overline{\mathrm{x}}_{\mathrm{i}}\right)+\sum_{\mathrm{i}=1}^{\mathrm{m}}\left(\mathrm{x}_{\mathrm{i}}-\overline{\mathrm{x}}_{\mathrm{i}}\right) \frac{\partial \mathrm{g}\left(\mathrm{x}_{\mathrm{i}}\right)}{\partial \mathrm{x}_{\mathrm{i}}}
$$

The first and second moments of $\mathrm{z}$ by ignoring terms higher than the second degree lead to the expected value $\mathrm{E}$ and the variance as: 


$$
\mathrm{E}(\mathrm{z})=\overline{\mathrm{z}}=\mathrm{g}\left(\overline{\mathrm{x}}_{\mathrm{i}}\right) ; \quad \operatorname{Var}(\mathrm{z})=\sum_{\mathrm{i}=1}^{\mathrm{m}} \mathrm{C}_{\mathrm{i}}^{2} \operatorname{Var}\left(\mathrm{x}_{\mathrm{i}}\right)
$$

and the standard deviation as

$$
\sigma=\left[\sum_{\mathrm{i}=1}^{\mathrm{m}}\left(\mathrm{C}_{\mathrm{i}} \sigma_{\mathrm{i}}\right)^{2}\right]^{1 / 2}
$$

where $\sigma_{z}$ and $\sigma_{i}$ are the standard deviations of $z$ and $x_{i}$, respectively. In these expressions, the $C_{i}$ values are partial derivations of $\frac{\partial \mathrm{g}\left(\mathrm{x}_{\mathrm{i}}\right)}{\partial \mathrm{x}_{\mathrm{i}}}$ calculated in terms of means $\left(\overline{\mathrm{x}}_{1}, \overline{\mathrm{x}}_{2}, \ldots \ldots, \overline{\mathrm{x}}_{\mathrm{m}}\right)$. These derivations are based on the assumption that variables are statistically independent of each other. On the other hand, risk of failure is defined in probability term as, $\mathrm{P}_{\mathrm{f}}=\mathrm{P}(\mathrm{z}<0)$. If $\mathrm{z}$ has normal distribution, then it can be expressed as

$$
\mathrm{P}_{\mathrm{f}}=1-\phi\left[\frac{\mathrm{E}(\mathrm{z})}{\sigma(\mathrm{z})}\right]=1-\phi(\beta)
$$

where $\phi(\beta)$ is obtained from the cumulative standard normal distribution tables. In the MFOSM method, the reliability index for $\beta$ can be found as follows:

$$
\beta=\frac{g\left(\bar{x}_{i}\right)}{\left[\sum_{i=1}^{m}\left(C_{i} \sigma_{i}\right)^{2}\right]^{1 / 2}}
$$

The risk calculated in this way is approximate, and if the $\mathrm{x}_{\mathrm{i}}$ variables fit normal distribution and the $\mathrm{g}$ (.) functions written as a linear combination of the base variables, the result will be complete and correct (Bayazit and Oguz, 1985).

The risk assessed by this method may be significantly different from the real risk because the probability distributions of variables of this type vary considerably and have skewness coefficients, and the correction done in the MFOSM method and the $g$ (.) function is determined in terms of the average values (Turkman, 1990).

AFOSM method shows how to calculate the performance function by linearizing the $\mathrm{z}$ function with the Taylor series expansion, not in the average values, but in terms of a point $\mathrm{x}^{*}=\left(\mathrm{x}_{1}{ }^{*}, \mathrm{x}_{2}{ }^{*}, \ldots, \mathrm{x}_{\mathrm{m}}{ }^{*}\right)$ on the dam break surface (Ang and Tang, 1984). The Taylor series expansion for such a point on the dam break surface can be expressed as

$$
\mathrm{z}=\mathrm{g}\left(\mathrm{x}_{1}{ }^{*}, \mathrm{x}_{2}{ }^{*}, \ldots, \mathrm{x}_{\mathrm{m}}{ }^{*}\right)+\sum_{\mathrm{i}=1}^{\mathrm{m}} \mathrm{C}_{\mathrm{i}}\left(-\mathrm{x}_{\mathrm{i}}-\mathrm{x}_{\mathrm{i}}^{*}\right) \text {; where } \mathrm{C}_{\mathrm{i}}=\frac{\partial \mathrm{g}}{\partial \mathrm{x}_{\mathrm{i}}}
$$

Here, since $\mathrm{z}=0$ is on the break surface, the breakpoint will have the condition of

$$
\begin{gathered}
\text { APPLIED ECOLOGY AND ENVIRONMENTAL RESEARCH 14(4): 589-606. } \\
\text { http://www.aloki.hu • ISSN } 15891623 \text { (Print) • ISSN } 17850037 \text { (Online) } \\
\text { DOI: http://dx.doi.org/10.15666/aeer/1404_589606 } \\
\text { (c) 2016, ALÖKI Kft., Budapest, Hungary }
\end{gathered}
$$




$$
\mathrm{g}\left(\mathrm{x}_{1}{ }^{*}, \mathrm{x}_{2}{ }^{*}, \ldots, \mathrm{x}_{\mathrm{m}}^{*}\right)=0
$$

The expected value of $\mathrm{z}$ can be written as

$$
E(z)=\sum_{i=1}^{m} C_{i}\left(-\bar{x}_{i}-x_{i}^{*}\right)
$$

and standard deviation is calculated with equation (9).

Furthermore, the $\mathrm{z}$ variable's standard deviation $\sigma_{\mathrm{z}}$ can be expressed as follows:

$$
\sigma_{\mathrm{z}}=\sum_{\mathrm{i}=1}^{\mathrm{m}} \alpha_{\mathrm{i}} \mathrm{C}_{\mathrm{i}} \sigma_{\mathrm{i}}
$$

Where

$$
\alpha_{i}=\frac{\mathrm{C}_{\mathrm{i}} \sigma_{\mathrm{i}}}{\left[\sum_{\mathrm{j}=1}^{\mathrm{m}}\left(\mathrm{C}_{\mathrm{j}} \sigma_{\mathrm{j}}\right)^{2}\right]^{1 / 2}}
$$

After the determination of $\alpha_{i}$ coefficient, one can write

$$
\mathrm{x}_{\mathrm{i}}^{*}=\bar{x}_{\mathrm{i}}-\alpha_{\mathrm{i}} \sigma_{\mathrm{i}} \beta
$$

by placing the limit in the situation equation, $\beta$ is calculated by trial and error. Hence, the $x^{*}$ 's on the collapsed surface are calculated, after the calculation of $\alpha_{\mathrm{i}}$ 's and $\mathrm{x}^{*}$ 's. If $\beta$ does not change with trials, then the risk is calculated with equation (10), (Bulu, 1989).

To find the equivalent normal distribution value of a variable that does not fit normal distribution, the cumulative probabilities of the equivalent normal distribution and the probability density ordinates are considered to be equal to the non-normal distribution values (Ang and Tang, 1984). If one equals the cumulative probabilities at the $\mathrm{x}_{\mathrm{i}}{ }^{*}$ breakpoint, then

$$
\phi\left(\frac{\mathrm{x}_{\mathrm{i}}^{*}-\overline{\mathrm{X}}_{\mathrm{xi}}}{\sigma_{\mathrm{xi}}^{\mathrm{N}}}\right)=\mathrm{F}_{\mathrm{xi}}\left(\mathrm{x}_{\mathrm{i}}^{*}\right)
$$

and hence $\overline{\mathrm{x}}_{\mathrm{xi}}{ }^{\mathrm{N}}, \sigma_{\mathrm{xi}}{ }^{\mathrm{N}}$ are the average and standard deviation of the $\mathrm{x}_{\mathrm{i}}$ variables of the normal distribution. The explanations of different terms are as follows:

$\mathrm{F}_{\mathrm{xi}}\left(\mathrm{x}_{\mathrm{i}}{ }^{*}\right)=$ the original cumulative probability calculated at the $\mathrm{x}_{\mathrm{i}}{ }^{*}$ point.

$\phi()=$. the cumulative probability of the standard normal variable.

$$
\overline{\mathrm{X}}_{\mathrm{xi}}^{\mathrm{N}}=\mathrm{X}_{\mathrm{i}}^{*}-\sigma_{\mathrm{xi}}^{\mathrm{N}} \phi^{-1}\left(\mathrm{~F}_{\mathrm{xi}}\left(\mathrm{X}_{\mathrm{i}}^{*}\right)\right)
$$


$\mathrm{f}_{\mathrm{xi}}\left(\mathrm{x}_{\mathrm{i}}{ }^{*}\right)=$ the original probability density ordinate at the point $\mathrm{x}_{\mathrm{i}}{ }^{*}$,

$\varphi()=$. the standard normal variable probability density ordinate.

From the above equations, one can deduce that

$$
\sigma_{\mathrm{xi}}{ }^{\mathrm{N}}=\frac{\varphi\left\{\phi^{-1}\left[F_{x i}\left(x_{i}^{*}\right)\right]\right\}}{\mathrm{f}_{\mathrm{xi}}\left(\mathrm{x}_{\mathrm{i}}^{*}\right)}
$$

The break surface coordinates are:

$$
\mathrm{X}_{\mathrm{i}}^{*}=\overline{\mathrm{X}}_{\mathrm{xi}}-\alpha_{\mathrm{i}} \beta \sigma_{\mathrm{xi}}{ }^{\mathrm{N}}
$$

and hence, $\alpha_{i}$ can be calculated. The remaining procedures are carried out as in MFOSM. The details of the methods are available in Yenigun and Erkek (2002b).

\section{Software Implementation}

The introduced trend analysis was performed using a computer code named TAFW (Trend Analysis for Windows), which was developed by Gumus (2006), and improved by Yenigun et al. (2008). Further, risk analysis was performed using a computer code named DamRisk. This computer code was developed by Yenigun (2001) using Java programming language.

\section{Results and Discussion}

Trend analysis results are summarized in Table 4. According to results, no trend found in maximum flow values represents Çatalan, Demirdöven, Aslantaş, Arpaçay and Çaygören Dams. Extreme characteristics of maximum flow values may be the cause of this situation. In addition, a downward trend noticed for Manavgat, Oymapınar, Kemer and Kayaboğazı Dams is compatible with studies in the literature (Kahya and Kalayc1, 2004; Cigizoglu et al., 2005; Sen et al., 2012). Only upward trend is obtained for Almus Dam. Regional watershed characteristics may be the cause of this situation. Due to the scope of this study, it is neglected. Moreover, compatible results are obtained from Mann Kendall and Spearman's Rho test. This compliance makes the results more consistent and acceptable. Figure 2 shows the $u(t)$ and $u^{\prime}(t)$ values versus year for each dam, which are important parameters in trend analysis. A trend can be seen for high values of $u(t)$, and $u$ '(t) can be obtained by the backward series of $u(t)$. The intersection of $u(t)$ and $u^{\prime}(t)$ curves denotes, approximately, the beginning of the trend.

Overall results of risk analysis for 4 dams (Çatalan, Manavgat, Demirdöven and Oymapinar) from previous and present studies (1960-2012), are given in Table 5 and Table 6. In these tables, MFOMS and AFOSM risk values and the cases when the risks occur are given. For Çatalan, Manavgat and Oymapınar Dams, risk values are reduced when previous and present periods are considered. This situation is parallel to the downward trend of the maximum flows of these dams. For Demirdöven Dam, no risk is found in both studies. Although there is an upward trend for Almus Dam, no risk is found. Although it has no trend for maximum flows, a slightly increased risk is obtained 
for Çaygören Dam. In that case, we can consider that the small value of trend changes cannot significantly affect the risk levels of the dams, in the short term.

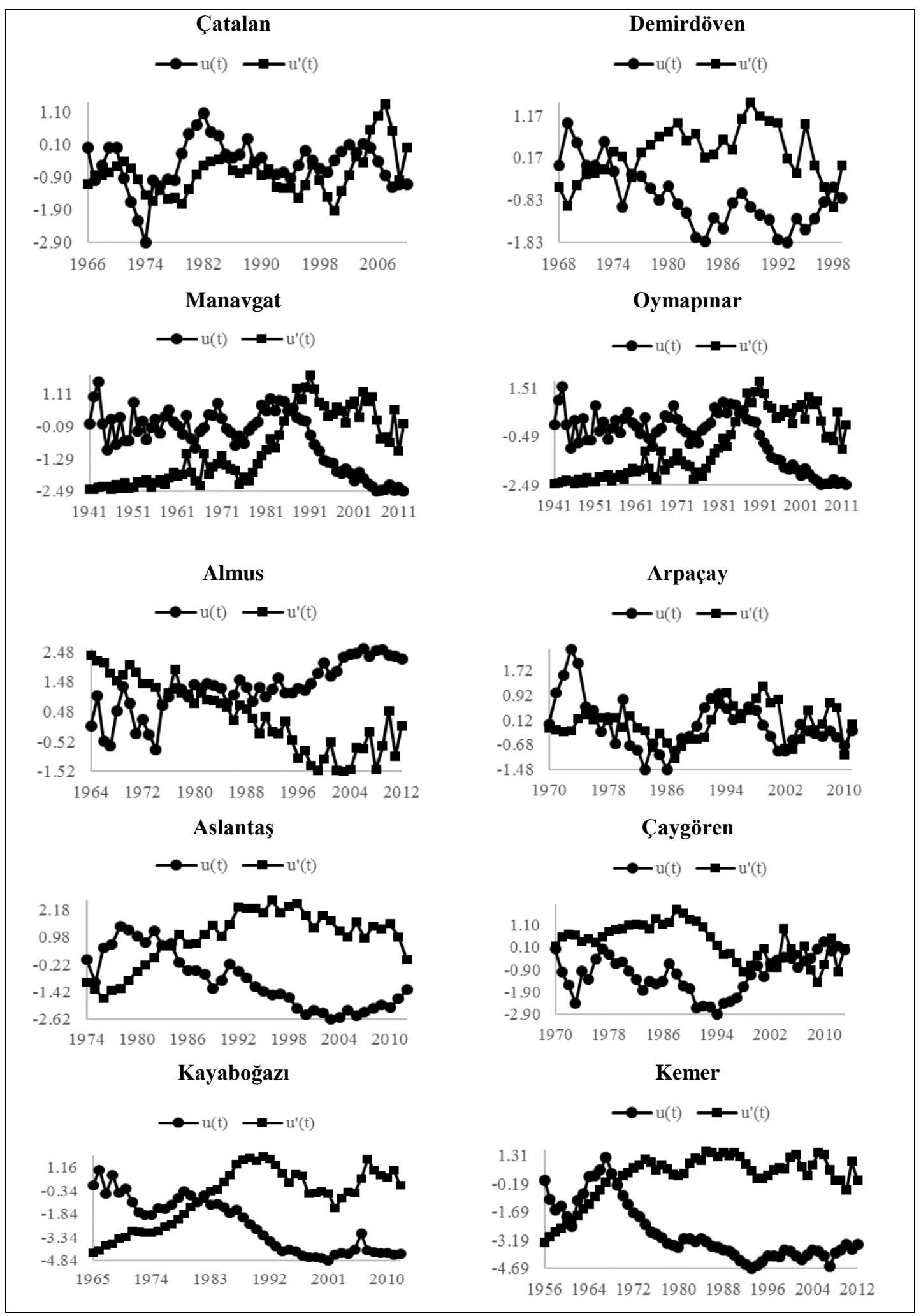

Figure 2. $u(t)$ and $u^{\prime}(t)$ values versus year for each dam. 
Table 4. The results of trend analysis

\begin{tabular}{|c|c|c|c|c|c|c|}
\hline \multirow[b]{2}{*}{ Dam } & \multicolumn{3}{|c|}{ Mann-Kendall Test Results } & \multicolumn{3}{|c|}{ Spearman's Rho Test Results } \\
\hline & $\begin{array}{c}\text { Kendall } \\
\text { Correlation } \\
\text { Coefficient }\end{array}$ & $\mathrm{Z}$ & Trend & $\begin{array}{l}\text { Rho Test } \\
\text { Value }\end{array}$ & $\mathrm{Z}$ & Trend \\
\hline Çatalan & -0.12 & -1.11 & - & -0.17 & -1.13 & - \\
\hline Demirdöven & -0.06 & -0.50 & - & -0.08 & -0.47 & - \\
\hline Manavgat & -0.20 & -2.43 & $\boldsymbol{\nabla}$ & -0.34 & -2.64 & $\boldsymbol{\nabla}$ \\
\hline Oymapınar & -0.20 & -2.43 & $\nabla$ & -0.34 & -2.64 & $\boldsymbol{\nabla}$ \\
\hline Almus & 0.23 & 2.35 & $\Delta$ & 0.34 & 2.38 & $\boldsymbol{\Delta}$ \\
\hline Arpaçay & -0.01 & -0.11 & - & -0.02 & -0.14 & - \\
\hline Aslantaş & -0.11 & -0.99 & - & -0.20 & -1.25 & - \\
\hline Çaygören & 0.01 & 0.13 & - & 0.04 & 0.28 & - \\
\hline Kayaboğazı & -0.43 & -4.35 & $\boldsymbol{\nabla}$ & -0.64 & -4.40 & $\boldsymbol{\nabla}$ \\
\hline Kemer & -0.30 & -3.28 & $\boldsymbol{\nabla}$ & -0.47 & -3.49 & $\boldsymbol{\nabla}$ \\
\hline
\end{tabular}

Table 5. Risk analysis results for 4 Dams from previous studies

\begin{tabular}{|c|c|c|c|c|}
\hline \multirow{2}{*}{ Dam } & \multicolumn{2}{|c|}{ Past Period } & \multirow{2}{*}{ Remarks } & \multirow{2}{*}{ Reference } \\
\hline & MFOSM & AFOSM & & \\
\hline Çatalan & $0.0409^{\mathrm{a}}$ & 0.0000 & a: MFOSM risk when $m=5$ gated closed & (Yenigun and Erkek, 2002b) \\
\hline Demirdöven & 0.0000 & 0.0000 & & (Yenigun and Erkek, 2007) \\
\hline Manavgat & $0.0003^{\mathrm{b}}$ & $0.0002^{\mathrm{c}}$ & $\begin{array}{l}\text { b: MFOSM risk when } \mathrm{m}=2 \text { gated closed } \\
\text { c: AFOSM risk when } \mathrm{Q}_{100} \text { situation occur }\end{array}$ & (Yenigun and Erkek, 2002b) \\
\hline Oymapınar & $0.3745^{\mathrm{d}}$ & $0.001^{\mathrm{e}}$ & $\begin{array}{l}\text { d: MFOSM risk when } \mathrm{m}=3 \text { gated closed } \\
\text { e: AFOSM risk when } \mathrm{Q}_{100} \text { situation occur }\end{array}$ & (Yenigun, 2001) \\
\hline
\end{tabular}

Table 6. Risk analysis results for 1960-2012 period.

\begin{tabular}{|c|c|c|l|}
\hline \multirow{2}{*}{ Dam } & \multicolumn{2}{|c|}{ Present Period } & \multirow{2}{*}{ Remarks } \\
\cline { 2 - 3 } & MFOSM & AFOSM & \\
\hline Çatalan & $0.0222^{\mathrm{a}}$ & 0,0000 & a: MFOSM risk when $\mathrm{m}=5$ gated closed \\
\hline Demirdöven & 0,0000 & 0,0000 & \\
\hline Manavgat & $0.0001^{\mathrm{b}}$ & $0.0002^{\mathrm{c}}$ & $\begin{array}{l}\text { b: MFOSM risk when } \mathrm{m}=2 \text { gated closed } \\
\text { c: AFOSM risk when } \mathrm{Q}_{100} \text { situation ocur }\end{array}$ \\
\hline Oymapınar & $0.2611^{\mathrm{d}}$ & $0.001^{\mathrm{e}}$ & $\begin{array}{l}\text { d: } \text { MFOSM risk when } \mathrm{m}=3 \text { gated closed } \\
\text { e: AFOSM risk when } \mathrm{Q}_{100} \text { situation ocur }\end{array}$ \\
\hline Almus & 0,0000 & 0,0000 & \\
\hline Arpaçay & 0,0000 & 0,0000 & \\
\hline Aslantaş & 0,0000 & 0,0000 & \\
\hline Çaygören & $0.0001^{\mathrm{f}}$ & 0,0000 & f: MFOSM risk when $\mathrm{m}=6$ gated closed \\
\hline Kayaboğazı & 0,0000 & 0,0000 & \\
\hline Kemer & 0,0000 & 0,0000 & \\
\hline
\end{tabular}


The DAM_RISK computer program was developed by the first author of the study in order to determine the following factors of spillways, and dams, in the face of hydraulic and hydrological loads of overflows of various return intervals:

- Performance

- Risk values, and

- Suitable dimension rehabilitation.

In addition to the determination of distribution and alternative overflow parameterization based on the dimensions obtained, risk analysis is used to evaluate risk and reliability for all alternative dimensions. The program also has the following features:

- The dams' risks are determined by MFOSM and AFOSM using the projected discharge. In order to determine the risk with all its parameters, for a situation in which $\mathrm{m}$ gates of the spillway do not open, the risks that might have occurred are calculated (if dimensioning had been done based on this discharge), according to the overflow discharge for $\mathrm{n}$ years for which risk values have been determined (which may vary as desired), and the results of these calculations are entered in the fourth section of the program. If the spillway is gateless, then calculations are made based solely on the projected discharge and the overflow discharge for $\mathrm{n}$ years for which risk values have been determined.

- In the dimension rehabilitation section, the effective spillway width (L) and spillway load $(\mathrm{H})$, which make up the spillways' dimensions, are considered in different stages.

As a result of dimension rehabilitation carried out for these dams, risk values were found. The risk becomes zero if dimensioning is performed according to the data determined by the program.

Nonetheless, even when the risk is numerically determined to be zero, the risk never completely disappears. This point must be carefully taken into consideration in every application. It must not be forgotten that the data used in the calculation are stochastic in nature, particularly hydrologic and meteorological data, and thus the observed values may change over time.

The reservoir damping factor, which is a function of the reservoir volume at normal water level, versus the reservoir volume at maximum water level, is extremely important in both MFOSM and AFOSM for determination of risk value. This factor is important in obtaining preliminary information for use in future studies.

For the same dam, a different graphic evaluation can easily be carried out for some of the risks obtained showing different dimensions that yield the same risks. Thus, it is clear that effective data can be obtained in cost analysis for any dimension rehabilitation project.

It can be said that the derived risk is in consonance with trend analysis results, which may be affected by climate change or other reasons. On the other hand, climate change is a very complex fact, and such kind of inferences should be supported by further studies, Serinaldi and Kilsby (2015). 


\section{Conclusions}

In this study, the possible impact of climate change on maximum flow values, and the variation of spillway risk levels of selected dams under this possible impact are investigated. For this purpose, trend and risk analyses were performed within the scope of study.

Downward or no trend is obtained for almost all of the maximum flow values of investigated dams. This situation can also be monitored when the spillway risks for previous and present periods are examined. The entire risk values reduced or remained stable as (0), except a slight increase for one dam. The main reason for this can be indicated as the effect of climate change on precipitation. Many pieces of research cited in the study supports this inference. The dams studied are evaluated as safe, when the present long-term maximum flow values are considered. Results show us the processes for obtaining the updated maximum flow data, and its effect on risk levels for dam safety; using effective methods are crucial for prediction and prevention of the flood damages.

The DAM_RISK program will process the observed maximum flow statistically, using these to calculate the reliability performance and risk value of dams in the face of the overflow value that may occur; and determining suitable dimension rehabilitation that may be proposed in situations where risk occurs, thus rendering the rehabilitation ready for technical and financial analysis.

This approach can be used as an important evaluation mechanism for dams still in the project phase, just as it can determine risk values for dams under construction and in operation, based on observed flow values. Thus a dam can undergo necessary revision, while still in the planning stage.

Moreover, the fact that the rehabilitation is included in the same program provides rapidity and ease of use. The program not only determines the dam safety level but also indicates how the dam can be made safer.

A diagram with the obtained dimensions shows safety evaluator as the numerically riskless region, which comprises the most suitable dimension values based on the characteristics of the location of the dam, and the technical and financial considerations of the precautions to be taken (Yenigun and Erkek, 2007).

With developments such as distant perception techniques, which are currently gaining importance, the flow observations, being a fundamental part of real-time operations, can be directly monitored and evaluated by computer. And with the current risk values obtained in this way, as well as the early warning system, emergency intervention, risk and safety evaluation, it is possible to achieve a significant degree of personal safety and financial security.

This study may be extended by investigating different dams' future spillway risk performance through carrying out further predictive rainfall-runoff analysis (for 25 years, 50 years), using different climate change scenarios. Risk analyses may be performed based on related dams' reservoir volume instead of streamflow observations due to consider the complete effects on the catchment.

\section{REFERENCES}

[1] Ang, A.H.S., Tang, W.H. (1984): Probability Concepts In Engineering Planning And design, Vol.2, Decision, Risk And Reliability. - John Wiley And Sons Inc., USA.

[2] Bayazıt, M., Oğuz, B. (1985): Statistics for Engineers. - Birsen Publ., Istanbul, Turkey. (In Turkish) 
[3] Birsan, M.V., Molnar, P., Burlando, P., Pfaundler, M. (2005): Streamflow trends in Switzerland. - Journal of Hydrology 314: 312-329.

[4] Bouwer, L.M., Bubeck, P., Aerts, J. (2010): Changes in future flood risk due to climate and development in a Dutch polder area. - Global Environmental Change 20(3): 463-471.

[5] Bulu, A. (1989): Risk Analysis of Dams. - Mediterranean University, Journal of Isparta Engineering Faculty 4:19-29, Isparta, Turkey. (In Turkish)

[6] Burn, D.H., Elnur, M.A.H. (2002): Detection of hydrologic trends and variability. Journal of Hydrology 255: 107-122.

[7] Chang, C.W., Lin, P.S., Tsai, C.L. (2011): Estimation of sediment volume of debris flow caused by extreme rainfall in Taiwan. - Engineering Geology 123(1-2): 83-90.

[8] Cheng, S.T. (1993): Statistics of dam failures, reliability and uncertainty analyses in hydraulic design. - ASCE, New York, USA, p. 97.

[9] Cheng, Y., Hongming, H., Nannan, C., Wenming, H. (2016): The Effects of Climate and Anthropogenic Activity on Hydrologic Features in Yanhe River. - Advances in Meteorology, Vol.2016, Article ID 5297158.

[10] Chernet, H., Alfredsen, K., Midttømme, G. (2014): Safety of Hydropower Dams in a Changing Climate. - J. Hydrol. Eng. 19(3): 569-582.

[11] Cicek, I., Duman, N. (2015): Seasonal and Annual Precipitation Trends in Turkey. Carpathian Journal of Earth and Environmental Sciences 10 (2):77-84.

[12] Cigizoglu, H.K., Bayazit, M., Onoz, B. (2005): Trends in the maximum, mean and low flows of Turkish rivers. - Journal of Hydrometeorology 6( 3): 280-290.

[13] Condon, L.E., Gangopadhyay, S., Pruitt, T. (2015): Climate change and non-stationary flood risk for the upper Truckee River basin. - Hydrol. Earth Syst. Sci. 19: 159-175.

[14] Cooper, D.F., Chapman, C.B. (1993): Risk analysis for large projects. - John Wiley and Sons, USA.

[15] Demir, V., Kisi, O. (2016): Flood Hazard Mapping by Using Geographic Information System and Hydraulic Model: Mert River, Samsun, Turkey. - Advances in Meteorology, Vol 2016, Article ID 4891015.

[16] DSI, (2015): (General Directorate of Turkish Hydrualic State Works). web: http://rasatlar.dsi.gov.tr/ (accessed 3 February 2015)

[17] Egueen, M., Polo, M.J., Gulliver et al. (2015): Flood risk trends in coastal watersheds in South Spain: direct and indirect impact of river regulation. Changes in Flood Risk and Perception in Catchments and Cities. - Book Series: Proceedings of the International Association of Hydrological Sciences (IAHS) 370: 51-56.

[18] Fatti, C.E., Patel, Z. (2013): Perceptions and responses to urban flood risk: Implications for climate governance in the South. - Applied Geography 36: 13-22.

[19] Goodarzi, E., Ziaei, M., Teang, S.L. (2013): Introduction to Risk and Uncertainty in Hydrosystem Engineering. - Springer, New York.

[20] Gumus, V. (2006): Evaluation of Euphrates basin's streamflow with trend analysis, MSc thesis, Harran University, Graduate School of Natural and Applied Sciences, Department of Civil Engineering, Sanliurfa, Turkey. (In Turkish)

[21] Hamed, K.H., Rao, A.R. (1998): A modified Mann-Kendall trend test for auto correlated data. - Journal of Hydrology 204: 182-1196.

[22] Helsel, D.R., (1992): Hirsch RM. Statistical Methods in Water Resources. - Elsevier, Amsterdam.

[23] ICOLD (2015): (International Commission on Large Dams), 2014. http://www.icoldcigb.org/GB/Dams/dams_safety.asp (accessed 3 February 2015)

[24] Ikiel, C. (2005): Rainfall regime regions in Turkey (a statistical climate study). Proceedings of International Conference on Forest Impact on Hydrological Processes and Soil Erosion. - University of Forestry, Yundola, Bulgaria, pp. 108-116.

[25] Jamie, H. (2015): Climate-driven changes in UK river flows: A review of the evidence. Progress in Physical Geography 39(Special Issue,1): 29-48. 
[26] Jun, Y., Denghua, Y., Zhiyong, Y., Zhe, Y., Yong, Y., Hao, W., Xiaoliang, S. (2016): Research on Historical and Future Spatial-Temporal Variability of Precipitation in China. - Advances in Meteorology Vol.2016, Article ID 9137201.

[27] Jung, I.W., Bae, D.H., Kim, G. (2011): Recent trends of mean and extreme precipitation in Korea. - Int. J. Climatol. 31: 359-370.

[28] Kahya, E., Demirel, M.C., Piechota, T.C. (2007): Spatial grouping of annual streamflow patterns in Turkey. - Proceedings of 27th AGU Hydrology Days, Fort Collins, Colorado, pp. 169-176.

[29] Kahya, E., Kalayci, S. (2004): Trend analysis of streamflow in Turkey. - J. Hydrol. 289: $128-144$.

[30] Kalyanapu, A.J., Azad Hossain, A.K.M., Kim, J., Yigzaw, W., Hossain, F., Shum, C.K. (2013): Toward a Methodology to Investigate the Downstream Flood Hazards on the American River due to Changes in Probable Maximum Flood due to Effects of Artificial Reservoir Size and Land-Use/Land-Cover Patterns. - Earth Interactions, Volume 17, Paper No. 24.

[31] Kang, B., Lee, S.J., Kang, D.H., Kim, Y.O. (2007): A flood risk projection for Yongdam dam against future climate change. - Journal of Hydro-environment Research 1(2): 118125.

[32] Kendall, M.G. (1975): Rank Correlation Methods. - Charles Griffin, London.

[33] Kite, G.W. (1976): Frequency and risk analyses in hydrology, Inland waters directorate. Water Resources Branch, Applied Hydrology Division, Network Planning and Forecasting Section, Ottawa, Canada.

[34] Lee, B.S., You, G.J.Y. (2013): An assessment of long-term overtopping risk and optimal termination time of dam under climate change. - Journal of Environmental Management 121: 57-71.

[35] Mann, H.B. (1945): Non-parametric test against trend. - Econometrika 13: 245-259.

[36] Marengo, J.A., Tomasella, J., Uvo, C.R. (1998): Trends in streamflow and rainfall in tropical South America: Amazonia, Eastern Brazil and Northwestern Peru. - Journal of Geophysical Research 103(D2): 1775-1784.

[37] Robert, C., Balling, J., Mohammad, S., Keikhosravi, K., Shouraseni, S.R., Javad, K. (2016): Trends in Extreme Precipitation Indices in Iran: 1951-2007. - Advances in Meteorology Volume 2016, Article ID 2456809

[38] Sen, B., Topcu, S., Turkeș, M., Sen, B., Warner, J.F. (2012): Projecting climate change, drought conditions and crop productivity in Turkey. - Clim Res. 52:175-191.

[39] Serinaldi, F., Kilsby, C.G. (2015): Stationarity is undead: Uncertainty dominates the distribution of extremes. - Advances in Water Resources 77: 17-36.

[40] Shi, P., Qiao, X., Chen, X., Zhou, M., Qu, S., Ma, X., Zhang, Z. (2014): Spatial distribution and temporal trends in daily and monthly precipitation concentration indices in the upper reaches of the Huai River, China. - Stoch. Environ. Res. Risk Assess. 28: 201-212.

[41] Sneyers, R. (1990): On the Statistical Analysis of Series of Observations. - Technical Note no. 143, WMO-no. 415, World Meteorological Organization, Geneva, Switzerland.

[42] Sowers, J., Vengosh, A., Weinthal, E. (2011): Climate change, water resources, and the politics of adaptation in the Middle East and North Africa. - Climatic Change 104 (3-3): 599-627.

[43] Stratz, S.A., Hossain, F. (2014): Probable Maximum Precipitation in a Changing Climate: Implications for Dam Design. - Journal of Hydrologic Engineering 19: 12.

[44] Suroso, D.S.A., Kombaitan, B., Setiawan, B. (2013): Exploring the use of risk assessment approach for climate change adaptation in Indonesia: Case study of flood risk and adaptation assessment in the South Sumatra province. - Procedia Environmental Sciences (17) $372-381$.

[45] Turkman, F. (1990): Identification of Risk and Reliability of Water Structures. - The Seminar of Water Engineering Problems, DSİ TAKK, Ankara, Turkey. (In Turkish) 
[46] Uzel, T. (1991): Barajların Güvenligi. - Doğan Publ, Istanbul.

[47] Vischer, D.L., Hager, W.H. (1998): Dam hydraulics. - John Wiley and Sons Pub, USA.

[48] WMO, (World Meteorological Organization) (1988): Analyzing Long Time Series of Hydrological Data with Respect to Climate Variability. - WMO, Geneva, Switzerland, WCAP-3, WMO/TD- No: 224, pp. 1-12.

[49] Yen, B.C., Tung, Y.K. (1993): Some recent progress in reliability analysis for hydraulic design, reliability and uncertainty analyses in hydraulic design. - ASCE, New York, USA, p 35.

[50] Yenigun, K. (2001): "Barajlarda Güvenilirlik ve Dolusavak Boyutlarının Risk Düzeyine Etkisi." - Istanbul Technical University, Natural and Applied Sciences Institute, Water Engineering Programme, $\mathrm{PhD}$ Thesis, Istanbul. (In Turkish)

[51] Yenigun, K. (2007): "Dolusavaklarda Taşkına Dayalı Güvenilirlik ve Baraj_risk Programıyla Risk Analizi Uygulaması.” - 1. Ulusal Baraj Güvenliği Sempozyumu, May 28-30, Ankara. (In Turkish)

[52] Yenigun, K., Ecer, R. (2013): "Climatic Change Impact on Water Resources by Overlay Mapping Technique." - Meteorological Applications 20: 427-438.

[53] Yenigun, K., Erkek, C. (2002a): "Mevcut Barajlarda Dolusavak Proje Boyutlarının Taşkın Riski İle Boyut Rehabilitasyonu-Güvenilirlik İlişkisi Üzerine Bazı İrdelemeler." Fifth International Congress on Advances in Civil Engineering, September 25-27, Istanbul. (In Turkish)

[54] Yenigun, K., Erkek, C. (2002b): "Risk Mühendisliği Yaklaşımıyla Baraj Güvenliğinin İrdelenmesi.” - GAP IV. Mühendislik Kongresi, C:2, S:1116-1125. (In Turkish)

[55] Yenigun, K., Erkek, C. (2007): "Reliability in dams and the effects of spillway dimensions on risk levels" - Water Resources Management 21(4): 747-760.

[56] Yenigun, K., Gümüş, V., Bulut, H. (2008): "Trends in Streamflow of Euphrates Basin, Turkey."- ICE Water Management 161(4): 189-198.

[57] Yerramilli, S. (2013): Potential Impact of Climate Changes on the Inundation Risk Levels in a Dam Break Scenario. - ISPRS Int. J. Geo-Inf. 2:110-134.

[58] Yue, S., Pilon, P.J., Phinney, B. (2003): Canadian streamflow trend detection: Impacts of serial and cross correlation. - J. Hydrol. Sci. 48(1): 51-64.

[59] Zhang, Q., Gemmer, M., Chen, J. (2008): Climate changes and flood/drought risk in the Yangtze Delta, China, during the past millennium. - Quaternary International 176-177: 62-69. 